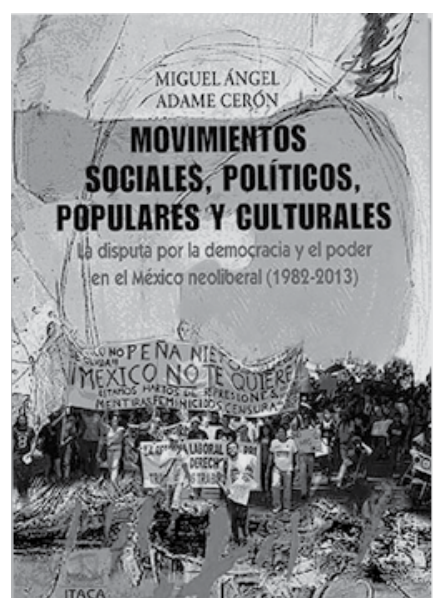

The Dispute for Democracy: Social Movements in Mexico

JAIME ORTEGA REYNA Universidad Nacional Autónoma de México, Facultad de Filosofía y Letras, Distrito Federal, México jaime_ortega83@hotmail.com

Desacatos 50 , enero-abril 2016, pp. 206-208
- Movimientos sociales, políticos, populares y culturales: la disputa por la democracia y el poder en el México neoliberal (1982-2013)

Miguel Ángel Adame Cerón, 2013 Instituto Nacional de Antropología/ Ítaca, México, 158 pp.

\section{La disputa por la democracia: movimientos sociales en México}

\author{
JAIME ORTEGA REYNA
}

iguel Ángel Adame Cerón nos entrega un breve ensayo en el que explora las principales aristas generadas por los movimientos sociales y políticos en México. Ubicado como un trabajo de antropología política, el autor busca trascender los límites disciplinarios para contextualizar, caracterizar y explorar las posibilidades de las movilizaciones en México en tiempos recientes, así como discutir las interpretaciones y conceptualizaciones a su alrededor. El marco temporal sobre el que se asienta el ensayo transcurre desde la implementación abierta del neoliberalismo durante el gobierno de Miguel de la Madrid Hurtado, en 1982. Adame Cerón caracteriza, a partir de una amplia bibliografía, el significado de la instalación de esta forma de acumulación de capital novedosa para el contexto político, que sustituyó y desplazó a la de los años cuarenta del siglo pasado. Se trata de un cambio radical en el despliegue de las relaciones sociales de capital, en las que se señalan dos elementos fundamentales: su relación con el conjunto de la fuerza de trabajo y el lugar del Estado en el nuevo contexto.

Se exploran los antecedentes de los movimientos sociales más importantes, en dos cortes. El primero se expresaría en la crisis causada 
por el terremoto de 1985 y la experiencia autoorganizativa de la sociedad, que desbordaría al Estado en su capacidad de solventar las principales demandas de la población afectada. Como correlato de este evento, habría un momento extensivo en la insurgencia neocardenista en las elecciones de 1988. Estos son los momentos previos al acercamiento de lo que en verdad interesa al autor: los movimientos desplegados a partir de 1994 con la insurgencia zapatista. Este movimiento surge al calor de la década de 1990 y del momento neoliberal radical del gobierno de Carlos Salinas de Gortari, pero se mantiene hasta tiempos recientes como un actor político e ideológico importante.

De esta manera, el ensayo centra sus baterías en la comprensión de los movimientos sociales más relevantes que tendrían como característica esencial buscar la ampliación de la democracia en términos de contenido y no sólo a partir de una definición formalista. Se trata de explorar estas movilizaciones, entre las que destacan las policías comunitarias en Guerrero, la Asamblea Popular de los Pueblos de Oaxaca, el movimiento que apostaba por la transparencia electoral en 2006, el Movimiento \#YoSoy132 y el Movimiento por la Paz con Justicia y Dignidad encabezado por Javier Sicilia. El autor explora media decena más de movilizaciones que se le presentan como tendentes a la democratización de la sociedad, y en ese sentido, ante la situación imperante en el país como posibles "movimientos antisistémicos".

La elección de los principales movimientos sociales con características democratizantes, que reconceptualizan lo público y lo común, y resisten a estrategias de despojo y mercantilización, tiene como sustento la noción de Estado y democracia del autor. México no puede considerarse un país democrático y el contenido de los movimientos sociales es una ratificación de esto. México se

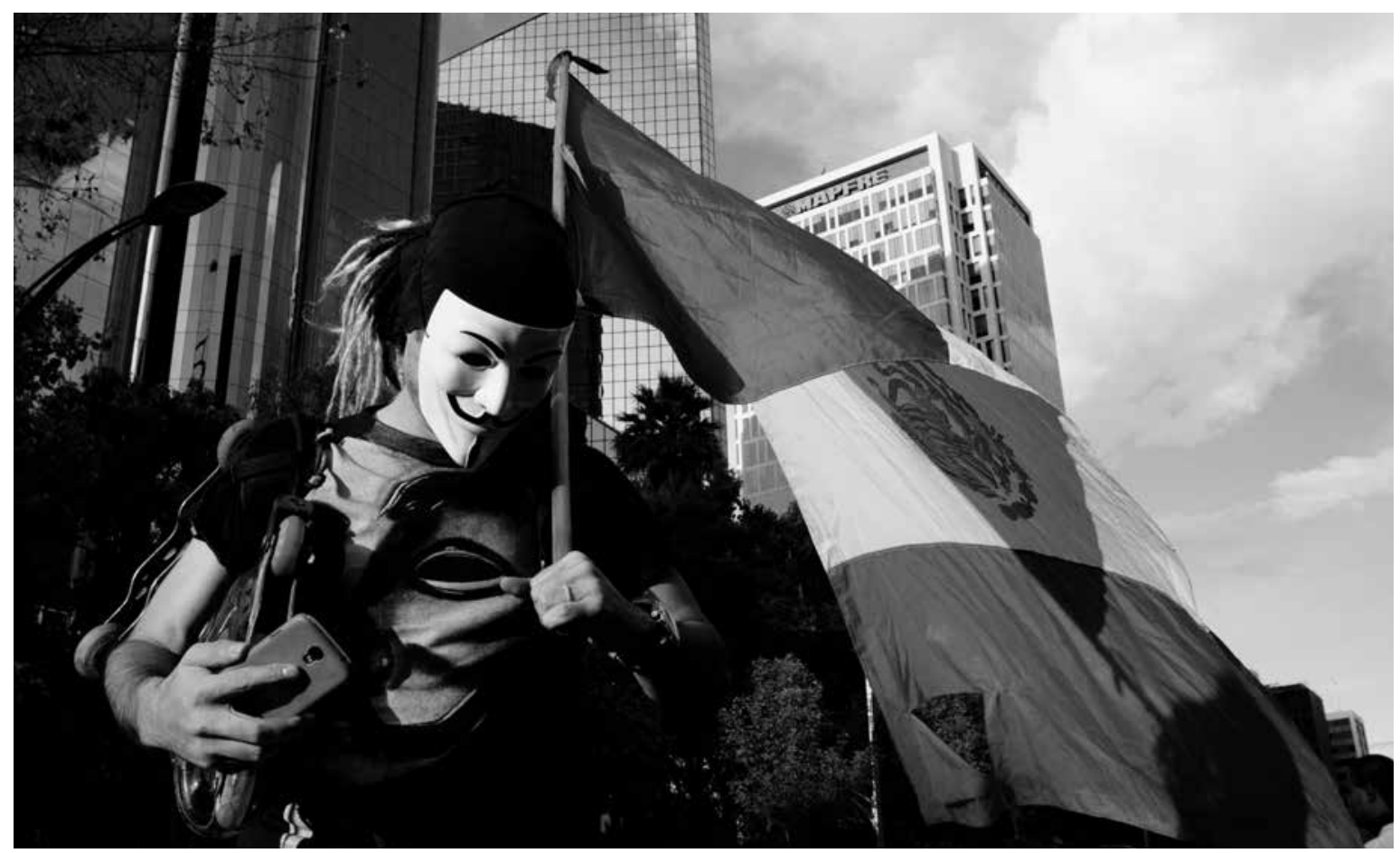

Octavio Hoyos • Marcha "Una luz por Ayotzinapa". Ciudad de México, 22 de octubre de 2015. 
ubicaría como un país con un gobierno autoritario, cuya militarización de la sociedad y movilizaciones buscan resistir y ganar espacios democráticos. Esta situación es contundente a partir de 2006 con el ascenso al poder de Felipe Calderón Hinojosa, en medio de una tensa situación que incluye el señalamiento de un fraude electoral.

Aunque con matrices discursivas, tácticas de movilización diversas y orígenes heterogéneos, los movimientos sociales que el autor emplaza como parte del núcleo de su análisis tienen una característica en común: enfrentarse con estructuras políticas que han tendido no a la liberalización ni mucho menos a la democratización de la sociedad, sino al contrario, a la profundización de un autoritarismo expresado de diversas formas desde 2006. La tensión que se juega es múltiple para el análisis de los movimientos sociales. Por un lado, éstos aspiran a conquistar más derechos, pero plantean de manera ocasional y en momentos de crisis programas mucho más amplios y ambiciosos. Por otro lado, se enfrentan a estructuras institucionales que reciben las demandas por una vía de negociación muy limitada y responden con represión abierta, expresada justamente en la persistencia de núcleos autoritarios poderosos. Para Adame Cerón, el centro de la variedad de movilizaciones es justamente la disputa por grados de democratización de lo social, y cada vez más de lo político. Esto es, hemos asistido a la emergencia de movimientos cuyo eje central y articulador es la demanda de una mayor democracia en términos de lo institucional.

Al finalizar su análisis, Adame Cerón busca entablar un diálogo productivo con el reconocido investigador y conocedor de los movimientos sociales Jorge Alonso — destacado exponente del análisis teórico en numerosas vertientes contemporáneas dedicadas a entender las movilizaciones más recientes acontecidas en Latinoamérica, México y en Jalisco, su lugar de residencia-, en cuya obra encuentra la posibilidad de dialogar y construir nociones más precisas sobre el estudio de los movimientos sociales. Así, el autor presenta un ensayo con dos finalidades claras: por un lado, hacer un balance del conjunto de movimientos y movilizaciones que se han desarrollado en México durante el último periodo, identificado como la "época neoliberal", sobre la base del endurecimiento de las figuras y formas autoritarias que se han asentado en el Estado “democrático”, y por el otro, un diálogo teórico con múltiples discursos, entre los que destaca el de Alonso, que buscan captar la multidimensionalidad y riqueza de la sociedad democrática en movimiento. D 